\title{
An Efficient Synthesis of Phthalocyanines Based on an Unprecedented Double-Addition of Oximes to Phthalonitriles*
}

Maximilian N. Kopylovich, ${ }^{\dagger}$ Vadim Yu. Kukushkin, ${ }^{*}{ }^{, \dagger}$ Matti Haukka, ${ }^{\S}$ Konstantin V. Luzyanin, ${ }^{\dagger,}$ and Armando J. L. Pombeiro*,

Centro de Química Estrutural, Complexo I, Instituto Superior Técnico, Av. Rovisco Pais, 1049-001 Lisbon, Portugal, Department of Chemistry, St.Petersburg State University, 198904 Stary Petergof, Russian Federation, and Department of Chemistry, University of Joensuu, P.O. Box 111, FIN-80101, Joensuu, Finland.

\section{Supporting information}

\section{Experimental Section}

Measurements: all instruments and procedures were previously described. ${ }^{1}$

Route A. $\mathrm{NiCl}_{2} \bullet 2 \mathrm{H}_{2} \mathrm{O}^{1}(166 \mathrm{mg}, 1.00 \mathrm{mmol})$ is stirred in acetone $(5 \mathrm{~mL})$ at room temperature for $5 \mathrm{~min}$, whereupon 2-propanone or 2-butanone oxime $(4.00 \mathrm{mmol})$ and phthalonitrile, 4,5dichlorophthalonitrile or 4-nitrophthalonitrile $(2.00 \mathrm{mmol})$ are added and the reaction mixture is refluxed for $1 \mathrm{~d}$. The solid complex formed is separated by filtration, washed with three 10 -mL portions of acetone and dried in air at $20-25{ }^{\circ} \mathrm{C}$. Yields are $80-70 \%$. Slightly grayish almost colorless crystals for X-ray study were obtained by slow evaporation of methanol-chloroform solutions $(1: 1, \mathrm{v} / \mathrm{v})$ of $[\mathbf{1}] \mathrm{Cl}_{2} \cdot 2 \mathrm{H}_{2} \mathrm{O}-[\mathbf{4}] \mathrm{Cl}_{2} \cdot 2 \mathrm{H}_{2} \mathrm{O}$ at $c a .25{ }^{\circ} \mathrm{C}$.

[1] $\mathrm{Cl}_{2} \cdot 2 \mathrm{H}_{2} \mathbf{O}$. Anal. Calcd for $\mathrm{C}_{28} \mathrm{H}_{40} \mathrm{~N}_{8} \mathrm{Cl}_{2} \mathrm{NiO}_{6}$ : C, 47.08; H, 5.65; N, 15.69. Found: C, 47.01; $\mathrm{H}, 6.03 ; \mathrm{N}, 15.50$. $\mathrm{FAB}^{+}-\mathrm{MS}, \mathrm{m} / z: 605\left[\mathrm{M}_{\text {cation }}-\mathrm{H}\right]^{+} . \mathrm{mp}=230{ }^{\circ} \mathrm{C}(\mathrm{dec}$.) (colorless crystals turn dark blue at $\left.195^{\circ} \mathrm{C}\right)$. IR spectrum, selected bands, $\mathrm{cm}^{-1}: 3254 \mathrm{~s}$, br and $3044 \mathrm{~s}$, br $v(\mathrm{NH}), 2922 \mathrm{~m}-\mathrm{w} v(\mathrm{CH})$, 1670 vs $v(\mathrm{C}=\mathrm{N}), 1583$ s $\delta(\mathrm{NH})$.

[2] $\mathbf{C l}_{2} \cdot 2 \mathrm{H}_{2}$ O. Anal. Calcd for $\mathrm{C}_{32} \mathrm{H}_{48} \mathrm{~N}_{8} \mathrm{Cl}_{2} \mathrm{NiO}_{6}$ : C, 49.89; H, 6.28; N, 14.55. Found: C, 49.96; $\mathrm{H}, 5.87 ; \mathrm{N}, 14.77$. $\mathrm{FAB}^{+}-\mathrm{MS}, \mathrm{m} / z: 661\left[\mathrm{M}_{\text {cation }}\right]^{+} . \mathrm{mp}=231^{\circ} \mathrm{C}$ (dec.) (colorless crystals turn dark blue at $\left.163{ }^{\circ} \mathrm{C}\right)$. IR spectrum, selected bands, $\mathrm{cm}^{-1}: 3358 \mathrm{vs}$, br and $3172 \mathrm{vs}$, br $\mathrm{v}(\mathrm{NH}), 2839 \mathrm{~s} \mathrm{v}(\mathrm{CH}), 1669$ vs $v(\mathrm{C}=\mathrm{N}), 1583$ vs $\delta(\mathrm{NH})$.

[3] $\mathbf{C l}_{2} \cdot 2 \mathrm{H}_{2}$ O. Anal. Calcd for $\mathrm{C}_{28} \mathrm{H}_{36} \mathrm{~N}_{8} \mathrm{Cl}_{6} \mathrm{NiO}_{6}$ : C, 39.47; H, 4.29; N, 13.15. Found: C, 39.29; $\mathrm{H}, 4.26 ; \mathrm{N}, 12.73$. $\mathrm{FAB}^{+}-\mathrm{MS}, \mathrm{m} / z: 743\left[\mathrm{M}_{\text {cation }}-\mathrm{H}\right]^{+}$. $\mathrm{mp}=218^{\circ} \mathrm{C}$ (dec.). IR spectrum, selected bands, $\mathrm{cm}^{-1}: 3172$ vs, br and 3000 vs, br $v(\mathrm{NH}), 2851 \mathrm{~m}-\mathrm{w} v(\mathrm{CH}), 1675$ vs $v(\mathrm{C}=\mathrm{N}), 1577 \mathrm{~s} \delta(\mathrm{NH})$.

[4] $\mathrm{Cl}_{2} \cdot 2 \mathrm{H}_{2} \mathrm{O}$. Anal. Calcd for $\mathrm{C}_{32} \mathrm{H}_{46} \mathrm{~N}_{10} \mathrm{Cl}_{2} \mathrm{NiO}_{10}$ : C, 44.67; H, 5.39; N, 16.28. Found: C, 43.86; H, 5.30; N, 15.77. $\mathrm{mp}=228{ }^{\circ} \mathrm{C}\left(\mathrm{dec}\right.$.) (colorless crystals turn dark blue at $\left.186{ }^{\circ} \mathrm{C}\right)$. IR spectrum, selected bands, $\mathrm{cm}^{-1}: 3432 \mathrm{vs}$, br and $3212 \mathrm{vs,}$ br $v(\mathrm{NH}), 3021 \mathrm{~s} v(\mathrm{CH}), 1669 \mathrm{vs} v(\mathrm{C}=\mathrm{N}), 1592$ vs $\delta(\mathrm{NH}), 1538$ vs $v_{\text {as }}$ and 1347 vs $v_{\mathrm{s}}\left(\mathrm{NO}_{2}\right)$.

\footnotetext{
${ }^{\dagger}$ Centro de Química Estrutural, Instituto Superior Técnico

${ }^{\ddagger}$ Department of Chemistry, St.Petersburg State University

$\S$ Department of Chemistry, University of Joensuu
} 
Route B. (i) Preparation of complexes with symmetric Pcs. A finely ground mixture of $[1] \mathrm{Cl}_{2} \cdot 2 \mathrm{H}_{2} \mathrm{O}$ or $[2] \mathrm{Cl}_{2} \cdot 2 \mathrm{H}_{2} \mathrm{O}(1 \mathrm{mmol})$ and phthalonitrile $(2 \mathrm{mmol})$ is heated $\left(200{ }^{\circ} \mathrm{C}, 8 \mathrm{~h}\right)$, then allowed to cool to $20-25^{\circ} \mathrm{C}$, washed with three 5 -mL portions of methanol and three 5-mL portions of acetone and dried in air at room temperature, then purified by vacuum sublimation. Yield of 5 (dark blue powder) is 60-50\%. The reaction can be preformed in methanol upon reflux for $24 \mathrm{~h}$ and the product is purified by vacuum sublimation (yield is ca. 60\%). 6 (dark blue powder) is obtained from [3] $\mathrm{Cl}_{2} \cdot 2 \mathrm{H}_{2} \mathrm{O}$ and $\mathrm{Cl}_{2} \mathrm{C}_{6} \mathrm{H}_{2}(\mathrm{CN})_{2}$ and purified analogously; yield is ca. $50 \% .7$ (dark green-blue powder) is obtained from [4]Cl $2 \cdot 2 \mathrm{H}_{2} \mathrm{O}$ and $\left(4-\mathrm{NO}_{2}\right) \mathrm{C}_{6} \mathrm{H}_{3}(\mathrm{CN})_{2}$ and purified by refluxing in methanol (two 10$\mathrm{mL}$ portions), washing with warm concentrated hydrochloric acid $(5 \mathrm{~mL})$, with methanol (three $5-\mathrm{mL}$ portions) and with acetone $(5 \mathrm{~mL})$; yield is $c a .50 \%$.

(ii) Preparation of complexes with unsymmetric Pcs. A finely ground mixture of $[1] \mathrm{Cl}_{2} \cdot 2 \mathrm{H}_{2} \mathrm{O}$, [2] $\mathrm{Cl}_{2} \cdot 2 \mathrm{H}_{2} \mathrm{O}(1 \mathrm{mmol})$ and 4,5-dichlorophthalonitrile $(2.00 \mathrm{mmol})$ (giving 8) or 4-nitrophthalonitrile $(2.00 \mathrm{mmol})$ [giving 9, which can also be obtained starting from $[4] \mathrm{Cl}_{2} \cdot 2 \mathrm{H}_{2} \mathrm{O}(1 \mathrm{mmol})$ and phthalonitrile $(2 \mathrm{mmol})]$ or a finely ground mixture of $[4] \mathrm{Cl}_{2} \cdot 2 \mathrm{H}_{2} \mathrm{O}(1 \mathrm{mmol})$ and 4methylphthalonitrile (giving 10) is heated at $200{ }^{\circ} \mathrm{C}$ for $8 \mathrm{~h}$. The reaction can be performed in refluxing methanol for $24 \mathrm{~h}$ and the product $\mathbf{8}$ purified by vacuum sublimation. The other products are purified analogously to $\mathbf{7}$. Yields of $\mathbf{8 , 9}$ and $\mathbf{1 0}$ are $50-40 \%$.

5. Anal. Calcd for $\mathrm{C}_{32} \mathrm{H}_{16} \mathrm{~N}_{8} \mathrm{Ni}$ : C, 67.29; H, 2.82; N, 19.62. Found: C, 67.09; H, 2.85; N, 19.26. 5 was also identified by comparison of its IR spectrum with that of the commercially available NiPc and by the X-ray structure analysis which is in good agreement with the known structure ${ }^{2}$ of $\mathbf{5}$. The Xray identification was carried out using single crystal X-ray diffraction or powder diffraction data. The measured powder diffractograms were compared with the simulated diffractograms obtained from the single-crystal data.

6. Anal. Calcd for $\mathrm{C}_{32} \mathrm{H}_{8} \mathrm{~N}_{8} \mathrm{Cl}_{8} \mathrm{Ni}$ : C, 45.39; $\mathrm{H}, 0.95 ; \mathrm{N}, 13.23$. Found: $\mathrm{C}, 45.30 ; \mathrm{H}, 1.08 ; \mathrm{N}$, 13.55. IR spectrum, selected bands, $\mathrm{cm}^{-1}: 3365 \mathrm{~m}-\mathrm{w} v(\mathrm{NH}), 3087 \mathrm{~m}-\mathrm{w} v(\mathrm{CH}), 1645 \mathrm{~m}-\mathrm{w} v(\mathrm{C}=\mathrm{N})$, $1500 \mathrm{~m}-\mathrm{w} \delta(\mathrm{NH})$.

7. Anal. Calcd for $\mathrm{C}_{32} \mathrm{H}_{12} \mathrm{~N}_{12} \mathrm{O}_{8} \mathrm{Ni}$ : C, 51.16; H, 1.61; N, 22.37. Found: C, 50.54; H, 1.60; N, 21.93. IR spectrum, selected bands, $\mathrm{cm}^{-1}: 3310 \mathrm{~m}-\mathrm{w} v(\mathrm{NH}), 3098 \mathrm{~m}-\mathrm{w} v(\mathrm{CH}), 1609 \mathrm{~m}-\mathrm{w} v(\mathrm{C}=\mathrm{N})$, $1524 v_{\text {as }}$ and 1336 vs $v_{s}\left(\mathrm{NO}_{2}\right), 1527 \mathrm{~s} \delta(\mathrm{NH})$.

8. Anal. Calcd for $\mathrm{C}_{32} \mathrm{H}_{12} \mathrm{~N}_{8} \mathrm{Cl}_{4} \mathrm{Ni}$ : C, 54.21; H, 1.71; N, 15.81. Found: C, 55.06; H, 2.22; $\mathrm{N}$, 15.68. IR spectrum, selected bands, $\mathrm{cm}^{-1}$ : $3332 \mathrm{~m}-\mathrm{w} v(\mathrm{NH}), 3089 \mathrm{~m}-\mathrm{w} v(\mathrm{CH}), 1662 \mathrm{~m}-\mathrm{w} v(\mathrm{C}=\mathrm{N})$, $1518 \mathrm{~s} \delta(\mathrm{NH})$.

9. Obtained as a 6:4 mixture with 7. Anal. Calcd for $\left(\mathrm{C}_{32} \mathrm{H}_{14} \mathrm{~N}_{10} \mathrm{O}_{4} \mathrm{Ni}\right)_{0.6} \cdot\left(\mathrm{C}_{32} \mathrm{H}_{12} \mathrm{~N}_{12} \mathrm{O}_{8} \mathrm{Ni}\right)_{0.4}$ : C, 55.12; H, 1.91; N, 21.70. Found: C, 55.43; H, 2.10; N, 21.43. IR spectrum, selected bands, $\mathrm{cm}^{-1}: 3310$ m-w v(NH), $3098 \mathrm{~m}-\mathrm{w} v(\mathrm{CH}), 1602 \mathrm{~m}-\mathrm{w} v(\mathrm{C}=\mathrm{N}), 1523 \mathrm{v}_{\text {as }}$ and $1338 \mathrm{vs} \mathrm{v}_{\mathrm{s}}\left(\mathrm{NO}_{2}\right), 1538 \mathrm{~s} \delta(\mathrm{NH})$.

10. Obtained as a 7:3 mixture with 7. Anal. Calcd for $\left(\mathrm{C}_{34} \mathrm{H}_{18} \mathrm{~N}_{10} \mathrm{O}_{4} \mathrm{Ni}\right)_{0.7} \bullet\left(\mathrm{C}_{32} \mathrm{H}_{12} \mathrm{~N}_{12} \mathrm{O}_{8} \mathrm{Ni}\right)_{0.3}$ : C, 56.67; H, 2.31; N, 20.98. Found: C, 56.69; H, 2.48; N, 19.32. IR spectrum, selected bands, $\mathrm{cm}^{-1}: 3310$ m-w v(NH), $3098 \mathrm{~m}-\mathrm{w} v(\mathrm{CH}), 1612 \mathrm{~m}-\mathrm{w} v(\mathrm{C}=\mathrm{N}), 1527 \mathrm{v}_{\text {as }}$ and $1332 \mathrm{vs} \mathrm{v}_{\mathrm{s}}\left(\mathrm{NO}_{2}\right), 1531 \mathrm{~s} \delta(\mathrm{NH})$.

Route C. $\mathrm{NiCl}_{2} \bullet 2 \mathrm{H}_{2} \mathrm{O}(1.00 \mathrm{mmol})$, phthalonitrile $(4.00 \mathrm{mmol})$ and 2-propanone oxime or 2butanone oxime $(4.00 \mathrm{mmol})$ are treated as described for Route B. Yields are $c a .75 \%$.

Route D. Preparation of metal-free Pcs. The synthesis is analogous to Route $\mathbf{C}$ but without addition of the Ni salt. Yield 60-65\%, i.e. 15-10\% lesser than for Route C. 
11. Prepared from phthalonitrile. Anal. Calcd for $\mathrm{C}_{32} \mathrm{H}_{18} \mathrm{~N}_{8}$ : C, 74.70; H, 3.53; N, 21.78. Found: C, 74.66; H, 3.47; N, 21.14. 11 was also identified by comparison of its IR spectrum with that of the commercially available Pc and by the single crystal or powder X-ray diffraction analysis, which repeats the known structure ${ }^{[2]}$ of $\mathbf{1 1 .}$

12. Prepared from 4,5-dichlorophthalonitrile. Anal. Calcd for $\mathrm{C}_{32} \mathrm{H}_{10} \mathrm{~N}_{8} \mathrm{Cl}_{8}$ : C, 48.65; $\mathrm{H}, 1.28$; N, 14.18. Found: C, 48.66; H, 1.37; N, 14.14. IR spectrum, selected bands, $\mathrm{cm}^{-1}: 3290 \mathrm{~m}-\mathrm{W} v(\mathrm{NH})$, 3084 m-w v(CH), 1606 m-w v $(\mathrm{C}=\mathrm{N}), 1506 \mathrm{~s} \delta(\mathrm{NH})$.

13. Prepared from 4-phenoxyphthalonitrile. Anal. Calcd for $\mathrm{C}_{56} \mathrm{H}_{34} \mathrm{~N}_{8} \mathrm{O}_{4} \mathrm{Ni}$ : C, 71.43; $\mathrm{H}, 3.64$; N, 11.90. Found: C, 71.26; H, 3.73; N, 12.01. IR spectrum, selected bands, $\mathrm{cm}^{-1}: 3286 \mathrm{~m}-\mathrm{w} v(\mathrm{NH})$, $3037 \mathrm{~m}-\mathrm{w} v(\mathrm{CH}), 1588 \mathrm{~s} v(\mathrm{C}=\mathrm{N}), 1473 \mathrm{~s} \delta(\mathrm{NH})$. TLC on Merck $60 \mathrm{~F}_{254} \mathrm{SiO}_{2}$ plates: one spot, $R_{\mathrm{f}}=0.5$ (eluent is benzene : diethyl ether 1:20, v/v).

\section{Crystallographic details.}

The single-crystal X-ray diffraction data were collected with a Nonius KappaCCD diffractometer using Mo K $\alpha$ radiation $(\lambda=0.71073 \AA$ ). The powder diffraction data were collected with a BukerAXS Advance diffractometer equipped with Göbel mirrors, Soller slits and a scintillation detector. Single crystals were mounted in an inert oil to the cold gas stream of the diffractometer. The EvalCCD or Denzo-Scalepack program packages were used for cell refinements and data reduction. Structures were solved by direct methods using the SIR-2002 program.

A multiscan absorption correction based on equivalent reflections (XPREP in SHELXTL v. 6.14 or SADABS v2.10) was applied to all data $\left(\mathrm{T}_{\operatorname{man}} / \mathrm{T}_{\text {mix }}\right.$ values were $0.9400 / 0.8072,0.9001 / 0.8335$, $0.79337 / 0.65224$ for $[1] \mathrm{Cl}_{2} \bullet 4\left(\mathrm{H}_{2} \mathrm{O}\right),[2] \mathrm{Cl}_{2}$, and $[3] \mathrm{Cl}_{2} \bullet 2\left(\mathrm{CHCl}_{3}\right)$. The limited quality of the structural data of $[1] \mathrm{Cl}_{2} \bullet 4\left(\mathrm{H}_{2} \mathrm{O}\right)$ was due to the weak diffraction power and poor quality of the crystals. In $[1] \mathrm{Cl}_{2} \bullet 4\left(\mathrm{H}_{2} \mathrm{O}\right)$ the oxygen atom $\mathrm{O}(98)$ of the water molecule is disordered over two sites with occupancies of $c a$. 0.52:0.48. In [2] $\mathrm{Cl}_{2}$, the $\mathrm{CH}_{3}$ and $\mathrm{CH}_{2}$ groups in one of the $\mathrm{N}=\mathrm{Et}(\mathrm{Me})$ groups were disordered in two positions with occupation parameter ratio of ca. 0.61/0.39. All $\mathrm{NH}_{2}$ and $\mathrm{H}_{2} \mathrm{O}$ hydrogens were located from the difference Fourier map but only the $\mathrm{NH}_{2}$ hydrogens in the case of $[2] \mathrm{Cl}_{2}$ were refined isotropically. All the other hydrogens were placed in idealized position and constrained to ride on their parent atom.

Crystal data for $[1] \mathrm{Cl}_{2} \bullet 4\left(\mathrm{H}_{2} \mathrm{O}\right): \mathrm{C}_{28} \mathrm{H}_{44} \mathrm{Cl}_{2} \mathrm{~N}_{8} \mathrm{NiO}_{8}, \mathrm{M}=750.32$, monoclinic, space group $P 2_{1} / \mathrm{n}$, $a=12.7695(13), b=8.9459(8), c=15.7581(16) \AA, \beta=92.4970(10)^{\circ}, V=1798.4(3) \AA^{3}, Z=2$, $\rho_{\text {calcd }}=1.386 \mathrm{Mg} / \mathrm{m}^{3}, F(000)=788, \lambda\left(\mathrm{MoK}_{\alpha}\right)=0.71073 \AA, \mu=0.744 \mathrm{~mm}^{-1}, T=100(2) \mathrm{K}, 3091$ unique reflections $\left(\mathrm{R}_{\mathrm{int}}=0.0334\right), R\left(\right.$ on $\left.\mathrm{F}^{2}\right)=0.0732, w R 2\left(\right.$ on $\left.F^{2}\right)=0.2161(I>2 \sigma(I))$, GOOF $=1.095$.

Crystal data for [2] $\mathrm{Cl}_{2}: \mathrm{C}_{32} \mathrm{H}_{44} \mathrm{Cl}_{2} \mathrm{~N}_{8} \mathrm{NiO}_{4}, \mathrm{M}=734.36$, Monoclinic space group $P 2{ }_{1} / \mathrm{n}, a=$ $10.6235(11), b=9.2927(6), c=17.5169(15) \AA, \beta=95.820(8)^{\circ}, V=1720.4(3) \AA^{3}, Z=2, \rho_{\text {calcd }}=1.418$ $\mathrm{Mg} / \mathrm{m}^{3}, \mathrm{~F}(000)=772, \lambda(\mathrm{MoK} \alpha)=0.71073 \AA, \mu=0.768 \mathrm{~mm}^{-1}, T=120(2) \mathrm{K}, 3000$ unique reflections $\left(R_{\text {int }}=0.0477\right), R\left(\right.$ on $\left.F^{2}\right)=0.0516, w R 2\left(\right.$ on $\left.F^{2}\right)=0.1335(I>2 \sigma(I)), \mathrm{GOOF}=1.079$.

Crystal data for $[3] \mathrm{Cl}_{2} \cdot 2\left(\mathrm{CHCl}_{3}\right): \mathrm{C}_{30} \mathrm{H}_{34} \mathrm{Cl}_{12} \mathrm{~N}_{8} \mathrm{NiO}_{4}, \mathrm{M}=1054.76$, triclinic space group $P 1, a=$ $10.4825(8), b=11.3345(9), c=11.5961(8) \AA, \alpha=106.522(4), \beta=109.206(4), \gamma=110.491(4)^{\circ}, V=$ $1087.37(14) \AA^{3}, Z=1, \rho_{\text {calcd }}=1.611 \mathrm{Mg} / \mathrm{m}^{3}, F(000)=534, \lambda\left(\mathrm{MoK}_{\alpha}\right)=0.71073 \AA, \mu=1.229 \mathrm{~mm}^{-1}, T$ $=100(2) \mathrm{K}, 389$ unique reflections $\left(R_{\mathrm{int}}=0.0465\right), R\left(\right.$ on $\left.\mathrm{F}^{2}\right)=0.0406, w R 2\left(\right.$ on $\left.F^{2}\right)=0.0954(I>2 \sigma(I))$, $\mathrm{GOOF}=1.120$.

\section{References:}


(1) M. N. Kopylovich, A. J. L. Pombeiro, A. Fischer, L. Kloo, V. Yu. Kukushkin, Inorg. Chem. 2003, 42, 7239.

(2) L. Ruiz-Ramirez, A. Martinez, J. J. Sosa, J. L. Brianso, E. Estop, X. Alcobe, J. S. Chinchon, Afinidad 1986, 43, 337. 